\title{
Annals of Mathematics
}

(Founded by Ormond Stone)

EDITED BY
Ormond Stone
W. E. ByerLy
F. S. Woops

E. V. Huntington G. A. Bliss

J. K. Whittemore

PUBLISHED UNDER THE AUSPICES OF HARVARD UNIVERSITY

Issued quarterly. Subscription price, $\$ 2.00$ a volume. Address The Annals of Mathematics, 2 University Hall, Cambridge, Mass.; London, Longmans, Green \& Co, 39 Paternoster Row; Leipzig, Otto Harrassowitz, Querstrasse 14.

The following pamphlets, most of which have been reprinted from the ANNALS OF MATHEMatics, second series, will be sent postpaid on receipt of price by the Publication Office of Harvard University, 2 University Hall, Cambridge, Mass.

Maxime Bôcher, Regular Points of Linear Differential Equations of the Second Order. . 23 pp. $1896 . \quad$. $\quad . \quad$ • $\quad . \quad$.

W. F. OsGood, Introduction to Infinite Series. $71 \mathrm{pp}$. Second Edition. 1900. . . . . . . . . . . . . . . $\quad .75$

James Prerpont. Galois' Theory of Algebraic Equations. $67 \mathrm{pp}$. 1906. From vols. 1-2. . . . . . . . . . . . $\quad .75$

Maxime Bôcher, The Theory of Linear Dependence. 16 pp. 1901.

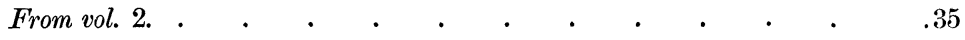

W. F. OsGood, Sufficient Conditions in the Calculus of Variations. 25 pp. 1901. From vol. 2. . . . . . . . . $\quad .50$

F. S. Woons, Space of Constant Curvature. 42 pp. 1902. From ro'. $3 . \quad .50$

W. F. OsGood, The Integral as the Limit of a Sum, and a Theorem of Duhamel's. 18 pp. 1903. From vol. 4. . . . . .

E. V. Huntington, The Continuum as a Type of Order : An Exposition of the Modern Theory. With an Appendix on the Transfinite Numbers. 63 pp. 1905 . From rols. 6-7. . . . .

MaXime Bôcher, Introduction to the Theory of Fourier's Series. 72 pp. 1906. From vol. 7. . . . . . . .

E. V. Huntington, Fundamental Laws of Addition and Multiplication in Elementary Algebra. $44 \mathrm{pp}$ 1906. From vol. 8. . . 


\section{Whole No. 162}

\section{CONTENTS}

The Fourteenth Summer Meeting of the American Mathematical Society. By Professor F. N. Cole - - - 53

On a Special Algebraic Curve Having a Net of Minimum Adjoint Curves. By Professor Virgil Snyder - $\quad 70$

Note on Certain Inverse Problems in the Simplex Theory of

Numbers. By Professor R. D. Carmichael - - 74

Third Report on Recent Progress in the Theory of Groups

of Finite Order. By Professor G. A. Miller - - 78 Notes

New Publications

Changes of address of members, exchanges, and subsoribers should be communicated at once to the Secretary of the American Mathematical Society, 501 West 116th Street, New York.

Subscriptions to the BULLETrN, orders for back numbers, and inquiries in regard to non-delivery of current numbers should be addressed to The Macmillan Company, 41 North Queen St., Lancaster, Pa., or 66 Fifth Avenue, New York.

The initiation fees and annual dues of members of the American Mathematical Society are payable to the Treasurer of the American Mathematical Society, Professor J. H. Tanner, Cornell Heights, Ithaca, N. Y.

Articles for insertion in the BuLLETIN should be addressed to the Bulletin of the American Mathematical Society, 501 West 116th Street, New York City.

The following dates have been fixed for the meetings of the Society :

$\begin{array}{lll}\text { Sat., Oct. 26, } & \text { A. M. } & \text { Sat., Feb. 29, 1908, 11:00 } \\ \text { Fri.-Sat., Dec. 27-28, "، 11:00 } & \text { " } & \text { Sat., A pr. 26, "“ }\end{array}$

The Meeting of December 27-28 will be the Annual Meeting of the Society for the Election of Officers.

The Southwestern Section will meet at Washington University, St. Louis, Mo., on Saturday, November 30, $190 \%$.

The Chicago Section will meet at the University of Chicago on Monday and Tuesday, December 30-31, $190 \%$. 